\title{
Withdrawal Restrictions in the Automobile
}

\section{Insurance Market}

\author{
Suzanne Yelen
}

Despite substantial increases in automobile insurance premiums in recent years, most American insurers lose money in the private automobile insurance market. ${ }^{1}$ Although premiums increased three times faster than inflation between 1984 and $1990,{ }^{2}$ American private insurers lost $\$ 2.4$ billion on personal auto insurance between 1980 and 1988, while other lines of property and casualty insurance gained $\$ 7.1$ billion. $^{3}$ A large portion of these losses derives from state mandates requiring private companies to write insurance at state regulated rates for drivers whom they deem too risky to insure voluntarily. While some states have created government-operated insurance programs, many of these programs have fared poorly, generating billion dollar deficits. ${ }^{4}$

The number of uninsured motorists, estimated at 17 million in 1991, has increased because some drivers could no longer afford insurance policies once insurance premiums soared. ${ }^{5}$ In response, legislators and regulators have increasingly held rates constant below expected claims, forcing insurers to suffer financial losses when covering high risk drivers. Responding in turn, some insurance companies resolved to leave the auto insurance market to avoid such losses.

To leave the market, insurers cease accepting new business and renewing existing policies. To prevent this exodus, two states-New Jersey and Massachusetts-passed regulations restricting insurance companies' withdrawal. ${ }^{6}$ In addition, California's Insurance Commissioner attempted to

1. A.M. BeSt Co., Best's Aggregates \& Averages: PROPERTY-Casualty 272-80 (1991).

2. National Ass'n of Ins. Comm'rs, 1990-1 NAIC PROC. 670, 671 (1989) (report of Robin Campaniano, Hawaii Insurance Commissioner).

3. Auto Coverage Losses Mount, Bus. INS., Dec. 25, 1989, at 41 [hereinafter Losses Mount].

4. Both New Jersey and Massachusetts have program deficits of over $\$ 3$ billion. See SEAN MOONEY, AUTO INSURANCE: CRITICAL CHOICES FOR THE 1990s 59 (1989); Jay Romano, New Law on Auto Insurance Draws Fire, N.Y. TIMES, Mar. 18, 1990, § 12NJ, at 1.

5. See Fannie Weinstein, Bane of the Highway: Uninsured Motorists, INS. REv., Nov. 1991, at 32.

6. See MASS. REGS. CODE tit. 211, §§ 54.01-.06 (1991); MASS. GEN. L. ch. 175, § 22H (1991); Rule of Operation 11, Commonwealth Automobile Reinsurers (Boston, Mass. 1991). The Commonwealth Automobile Reinsurers is the mechanism through which insurers in Massachusetts discharge their statutory duty to "cooperate ... [in providing] motor vehicle insurance to applicants who have been unable to obtain [voluntary market] insurance." MASS. GEN. L. ch. 175, § 113H (1991); N.J. ADMIN. CODE tit. 11, § 2-29 (1991). 
impose a difficult withdrawal procedure, but the California courts found that the procedure violated the California Insurance Code. ${ }^{7}$ Because withdrawal regulations essentially compel insurance companies to lose money selling auto insurance, an insurance executive described one state's efforts as "capital imprisonment."

Withdrawal regulations subvert the very goals of available and affordable insurance that they purport to achieve. Moreover, such regulations effect an unconstitutional taking of property ${ }^{9}$ and a denial of substantive due process rights. ${ }^{10}$ Part I of this Note describes the insurance crises that prompted legislators and regulators in New Jersey, California, and Massachusetts to enact withdrawal restrictions. Part II discusses these regulations in some detail, and Part III analyzes their economic effects. It argues that, although in the short run these provisions can compel insurance companies to bear the mounting costs of auto insurance, in the long run they produce perverse effects. The added costs and risks of the new regulations deter new insurance companies from entering the automobile insurance market and reduce the capital available to those companies that remain. Part IV examines the legal basis for withdrawal restrictions and concludes that New Jersey's and Massachusetts' regulations are unconstitutional. To address the soaring costs of auto insurance, legislators instead must develop a comprehensive solution.

\section{The CURREnT Auto Insurance Market}

The auto insurance market and the manner in which it is regulated have changed dramatically in the last twenty-five years. Before the 1970's, auto insurance rate regulations set rate floors for premiums to prevent insurance companies from becoming insolvent. In contrast, regulations now strive to keep rates down-sometimes even below the costs the insurance company must pay to provide such insurance-thereby forcing the companies to bear these rapidly escalating costs. ${ }^{11}$ Between 1982 and 1991, auto insurance rates increased by $109.5 \%$. However, during that same period, the main factors contributing to the costs of auto insurance also increased at high rates: bodily injury claim costs by $112.1 \%$; hospital room prices by $112.2 \%$; medical costs by $91.4 \%$; auto

7. Travelers Indem. Co. v. Gillespie, 785 P.2d 500 (Cal. 1990); see CAL. INS. CODE $\$ 1861.03$ (C) (West 1984 \& Supp. 1992).

8. Kathryn J. McIntyre, Industry Executives Face a Host of Pressing Concerns, Bus. INS., Oct. 22, 1990, at 82 (quoting William E. Thiele, President of the Continental Corp., referring to New Jersey).

9. "[N]or shall private property be taken for public use, without just compensation." U.S. CONST. amend. $\mathrm{V}$.

10. "[N]or shall any State deprive any person of life, liberty, or property, without due process of law." U.S. CONST, amend. XIV, \$1.

11. See BANks MCDOWEll, DEREgulation AND COMPETTTION IN THE INSURANCE INDUSTRY 14 (1989) (discussing insurers' self-regulatory attempts to maintain minimum rates); Mark Pauly et al., Regulation and Quality Competition in the US Insurance Industry, in THE ECONOMICS OF INSURANCE REgUlation: A CROSS-NATIONAl STUDY 65, 74 (Jörg Finsinger \& Mark V. Pauly eds., 1986). 
repair costs by $82.3 \%$; and property damage claim costs by $79.6 \% .^{12}$ Many drivers cannot afford the premiums necessary to cover the risks, especially urban residents, who tend to have higher risk factors than suburban residents. ${ }^{13}$ High auto insurance rates, combined with compulsory auto insurance laws, ${ }^{14}$ squeeze drivers who, in turn, pressure legislators and insurance regulators to ensure that auto insurance is available and affordable. ${ }^{15}$ In theory, the market could regulate rates, and those unable to afford the insurance premiums could not drive. Although other insurance markets place this burden of high rates on the insured, legislatures encounter great political pressure to treat auto insurance differently.

This different treatment stemming from political demands has resulted in regulation through rate ceilings. However, such ceilings merely cause insurance companies to sell only to those insureds whose policies will be profitable at the fixed rate. As a result, insurance becomes unavailable to many who want it, and could even afford it, if the state did not enforce a rate ceiling.

In states where regulators do not fix maximum rates, consumers whom most insurance companies consider undesirable risks can obtain insurance from firms that specialize in insuring high-risk drivers. The market for normal-risk drivers is called the standard voluntary market. Drivers who have higher than normal risk factors obtain insurance from companies specializing in high-risk drivers in the nonstandard voluntary market. ${ }^{16}$ These companies stay in business only by charging premiums that are higher, often considerably higher, than those charged in the standard market. Even so, consumers benefit because the insurance is available. ${ }^{17}$ For instance, Texas, Wyoming, and Utah have a free market system for auto insurance rates. In those states, between $10 \%$ and $20 \%$ of all drivers are insured in the nonstandard market and only a small

12. Special Report: Factors Influencing Auto Insurance on the Rise, EXECUTIVE LETTER (Ins. Info. Inst., New York, NY), Apr. 27, 1992, at 1; see National Ass'n of Ins. Comm'rs, 1989-1 NAIC Proc. 1, 5 [hereinafter 1989-1 NAIC Proc.] (statement of Rep. James Florio).

13. See Bethany A. Felter, Straightening Out the Auto Insurance Mess: National Association of Independent Insurers Annual Conference, BEST's REv., PROP.-CASUALTY INS. ED., Dec. 1989, at 106. Two factors increase insurance losses in cities as compared to suburban areas: 1) inner city residents tend to be poorer than suburban residents; and 2) urban areas have more cars per square mile. Because urban environments have so many cars concentrated in a relatively small space, states with large urban centers have the highest insurance rates, and thus the worst problems with auto insurance. See David N. Grubb, Solving the Auto Insurance Crisis in New Jersey 20 (Apr. 10, 1989) (unpublished manuscript, on file with author) (Grubb is Special Deputy Commissioner with the New Jersey Department of Insurance.).

14. See Compulsory Auto Insurance, INS. INFO. INST., Jan. 1992 (Ruth Gastel ed.) (stating that fortytwo states and the District of Columbia have compulsory auto insurance laws).

15. Most legislators and scholars focus on the affordability and availability of auto insurance because these factors are of primary concern to consumers. See, e.g., California Initiative Statute 103 (Prop. 103), $\S 2$ reprinted in Proposition 103 and Related Issues, INS. INFO. INST., Dec. 1991 (Ruth Gastel ed.); N.J. STAT. ANN. § 17:30E-2 (West 1985 \& Supp. 1992); National Ass'n of Ins. Comm'rs, 1991-2 NAIC PRoC. 50, 90 (1991) (statement of Roger M. Moak, Senior Vice President and General Counsel of the Insurance Services Office).

16. MOONEY, supra note 4 , at 21 .

17. See PAUl A. SAMUelson, ECONOMics 77-78 (14th ed. 1992) (showing how shortages of goods result whenever a maximum price is set below the market price). 
percentage of drivers need coverage in the involuntary market, ${ }^{18}$ made up of those drivers who cannot find coverage in either the standard or nonstandard markets. Setting maximum rates undermines the nonstandard market because companies serving high risk insureds cannot charge rates high enough to cover costs and therefore must exit the market. In states without nonstandard markets, the number of drivers in the involuntary market has increased dramatically. ${ }^{19}$ When insurers are allowed to charge rates corresponding to risk, most drivers are able to buy insurance in the voluntary market, and the burden of insuring the involuntary market decreases.

By holding rates down, and thus increasing the size of the involuntary market, states create an expensive problem for themselves - they must meet the needs of these drivers. Though a variety of approaches is possible, each is costly and potentially inefficient. By enforcing compulsory insurance laws in a lax manner, states enable drivers simply not to buy insurance. Yet the inadequacy of this solution-both for the driver and for society-becomes evident when the driver has an accident. States often deal with drivers shut out of the voluntary market by offering insurance themselves or by assigning such drivers to private insurance companies. Forty-two states and the District of Columbia use auto insurance plans in which the involuntary market is split up among the insurers that service the voluntary market. ${ }^{20}$ Some states employ joint underwriting associations, state-mandated pooling mechanisms through which all auto insurance companies share the premiums and losses of the involuntary market. Similarly, some states organize reinsurance facilities that accept assignments of unacceptable risks from private insurance companies and then allocate the premiums and the losses to the private insurers. Still other states run their own insurance systems, while requiring private auto insurance companies to pay the costs. ${ }^{21}$ All these plans require massive infusions of state resources and often operate at huge deficits. ${ }^{22}$

Rate ceilings not only saddle the state with the expensive task of insuring the expanded involuntary market, but also increase the burdens on voluntary market drivers because insurers must use the premiums of low-risk drivers to subsidize high-risk drivers. ${ }^{23}$ In 1986 , Massachusetts auto insurers paid $\$ 566$ million to subsidize the involuntary market—an average added cost of $\$ 363$ to each voluntary market policyholder. ${ }^{24}$ In 1989 , New Jersey charged each

18. MOONEY, supra note 4 , at 53.

19. See Pauly et al., supra note 11, at 104-05.

20. Compulsory Auto Insurance, supra note 14.

21. See Henry G. Hager, Is Pa.'s New Auto Law Working, NAT'L UNDERWRITER, PRoP. \& CASUALTY ED., Oct. 1, 1990, at 23; Paul E. Wish, Review \& Preview: Between a Rock and a Hard Place, BEST's REV., Prop.-Casualty INS. ED., Jan. 1988, at 26.

22. See infra text accompanying notes $39 \& 60$.

23. See Losses Mount, supra note 3; Elizabeth Levitan Spaid, Auto Insurers, Regulators Clash, Christian SCI. MONITOR, Oct. 7, 1991, at Econ. 7.

24. MOONEY, supra note 4 , at 57 . 
driver in the voluntary market a surcharge of $\$ 222$ to subsidize the involuntary market. ${ }^{25} \mathrm{~A}$ vicious cycle ensues. Insurance companies raise rates on low risk drivers to subsidize high risk drivers. But in response to the higher rates, more marginal low-risk drivers choose to forgo insurance or to enter the involuntary market, thereby depriving insurance companies of some of their consumer base and increasing the burden on the state-subsidized involuntary market. Paradoxically, drivers sometimes prefer to enter involuntary market plans because state regulators have held the premiums for involuntary insurance at the same level as those of the voluntary market. ${ }^{26}$

As a result of these market distortions, private insurance companies have incurred considerable losses on auto insurance policies. Many desire to leave the auto insurance market altogether. ${ }^{27}$ State regulators and legislators need insurance companies to continue writing policies in their state. If insurance companies leave the market, the legislature will have to make insurance available through a state plan or face voter anger. Moreover, states faced with huge deficits from state-run involuntary market insurance plans often wish to force private insurance companies to finance these deficits. This frustrates the state's desire to make auto insurance available. In order to keep the insurers in the market, some states have enacted statutes and regulations making it extremely difficult, if not impossible, for private insurance companies to leave the auto insurance market. ${ }^{28}$ State regulation of insurance companies-at least in New Jersey, California, and Massachusetts-is becoming broader, treating the insurers like public utilities. ${ }^{29}$

\section{THE ENACTMENT OF WITHDRAWAL REGULATIONS}

New Jersey, Massachusetts, and California have the highest automobile insurance premiums in the United States..$^{30}$ In addition to imposing new costs on insurers, these states have enacted regulations and statutes limiting the ability of insurers to withdraw from the market. As will be argued in Part III,

25. Grubb, supra note 13 , at 15 .

26. Grubb, supra note 13 , at 20 . Although drivers could leave the state in response to high auto insurance premiums, it is unlikely that someone would incur the significant expenses associated with moving in order to find lower insurance rates.

27. Eight companies have already withdrawn from New Jersey. Nine others are in the process of withdrawing while at least seven more are trying to get approval for their withdrawal plans. In Massachusetts, thirteen companies have withdrawn from the auto insurance market and another two are in the process of withdrawing. See infra notes 47, 65-67 and accompanying text; see also Lisa S. Howard, NAIC Examines Reasons for Market Withdrawals, NAT'L UNDERWRITER, PROP. \& CASUALTY ED., Jan. 7, 1991, at 2; National Ass'n of Ins. Comm'rs, 1991-1 NAIC Proc. 815 (1990) (statement of Patricia Borowski, Professional Insurance Agents).

28. See supra note 6 and accompanying text.

29. See Orin S. Kramer, Solvency and Rate Suppression: In the Insurance Industry, BEST'S REV., Prop.-Casualty INS. EdITION, Mar. 1992, at 25.

30. See Karen Tumulty, N.J.'s Escalating Auto Insurance Costs Trigger a California-Style Revolt, L.A. TIMES, Feb. 11, 1990, at A28. 
the enactment of these regulations will only worsen the already poor situations in these states.

\section{A. New Jersey}

New Jersey has the highest auto insurance premiums in the country. ${ }^{31}$ In 1972, New Jersey passed a compulsory auto insurance law ${ }^{32}$ requiring drivers to buy a higher level of insurance coverage than required by most other states. ${ }^{33}$ As a result of this law, auto insurance premiums increased $200 \%$ by $1983 .{ }^{34}$ Even with these increased rates, insurers were unable to cover losses, but regulators refused to allow rate increases sufficient to cover insurance operating and administrative costs. The number of drivers in the involuntary market rose from $9 \%$ in 1970 to $53 \%$ in 1989 . Rates set for the involuntary market remained at the same level as for the voluntary market. ${ }^{35}$ New Jersey has set the rate of return for auto insurance at $3.5 \%{ }^{36}$ Auto insurers incurred private passenger liability insurance losses of $-3.5 \%,-3.1 \%$ and $-6.1 \%$ as a percentage of direct premiums earned in 1988,1989 , and 1990, respectively. They had a return on net worth in auto insurance of $-3.7 \%,-3.0 \%$ and $-6.1 \%$ in the same respective years. ${ }^{37}$

In 1983, newly enacted legislation relieved the private insurers from bearing part of the cost of the involuntary market. The state established a Joint Underwriting Association (JUA) to service the involuntary market and funded it with a surcharge placed on all policies sold in the voluntary market and with funds obtained from vehicle violations and convictions. ${ }^{38}$ The insurance companies paid for a portion of the surcharge on insurance policies in the form of reduced profits. However, the insurers, in theory, were not responsible for any deficit resulting from this scheme. The initial funding proved insufficient; by 1990 , the JUA's deficit had grown to over $\$ 3$ billion. ${ }^{39}$ In 1989 , the New Jersey Department of Insurance found that high insurance rates in New Jersey were caused by high accident rates and inefficiencies in the no-fault law. ${ }^{40}$ It blamed the JUA's deficit on insufficient premiums. The same study found that JUA drivers had $68 \%$ more accidents per car than voluntary market

31. 1989-1 NAIC PROC., supra note 12 , at 5 .

32. N.J. STAT. ANN. $\S \S 39: 6$ A-1 to $39: 6 A-35$ (West 1990 \& Supp. 1992).

33. MOONEY, supra note 4 , at 57-58.

34. Grubb, supra note 13 , at 17; 1989-1 NAIC PRoc., supra note 12, at 5.

35. Grubb, supra note 13, at 17; 1989-1 NAIC PROC., supra note 12, at 5.

36. N.J. ADMIN. CODE tit. 11, § 3-16.10 (1991).

37. National ASS'N OF INS. COMM'Rs, REPORT ON Profitability by LiNe by STATE 1990 (1991) [hereinafter NAIC REPORT ON PROFITABILITY] (Profitability Results-Six Year Summary: New Jersey). In contrast, New Jersey insurance companies earned profits of $12.5 \%, 9.6 \%$, and $8.2 \%$ on all lines of insurance sold during each respective year. The total return on net worth for all lines of New Jersey insurance, including auto insurance, during the same period was $18.5 \%, 12.9 \%$, and $10.8 \%$. $I d$.

38. N.J. STAT. ANN. §§ 17:30E-1 to 17:30E-24 (West 1985 \& Supp. 1992).

39. Romano, supra note 4.

40. Grubb, supra note 13 , at 18. 
drivers, but that rates were about the same as in the voluntary market. These rates remained approximately the same between 1984 and 1989 despite inflation and increased accident frequency. ${ }^{41}$

In response to these excesses, James Florio made reform of the insurance industry a cornerstone of his 1989 gubernatorial campaign. ${ }^{42}$ Soon after he took office, the legislature passed the Fair Automobile Insurance Reform Act (FAIR). ${ }^{43}$ This legislation dissolved the JUA and transferred its two million policyholders to the Market Transition Facility (MTF). The rates set for the MTF were initially set at the same level as the JUA, and thus, too low to cover costs. Under Florio's plan, drivers covered by the MTF switch gradually into the voluntary market so that only $10 \%$ of the drivers remain in the MTF by September 1993. These remaining drivers will be placed in an assigned risk pool similar to that in place before the JUA. Two studies have determined that the MTF would run up a deficit of $\$ 1$ billion by the time of its dissolution if rates were held at the same level as the JUA. ${ }^{44}$ Although FAIR requires the Insurance Commissioner to set rates so that the MTF is self-sustaining, it also requires private insurers to pay off $\$ 1.4$ billion of the debt incurred by the JUA and any debts incurred by the MTF if it is not self-sustaining. ${ }^{45}$ In March 1990, in response to the considerable costs that Florio's plan promised for insurance companies, several major insurance companies, including Allstate Insurance Company, the largest insurer in New Jersey, ${ }^{46}$ announced that they no longer wanted to write auto insurance in New Jersey. ${ }^{47}$

41. See Grubb, supra note 13, at 20; see also Kramer Associates, Perspective on the New Jersey Residual Market Experience (1990) (unpublished report, on file with author).

42. See Eric N. Berg, Largest Insurer in New Jersey, Allstate, Seeks to End Coverage, N.Y. TIMES, Sept. 17, 1991, at A1; Bruce Frankel, Allstate Says It's Leaving N.J., Cites Florio's Reform, USA TODAY, Sept. 18, 1991, at 3A.

43. N.J. STAT. ANN. $\S \S 17: 33 B-1$ to 17:33B-63 (West Supp. 1992); Romano, supra note 4.

44. Jay Romano, Auto Insurance: Do the Fixes Need Fixing?, N.Y. TIMES, Nov. 10, 1991, \$ 12NJ, at 1.

45. N.J. STAT. ANN. $\$ \S 17: 30 \mathrm{~A}-16(\mathrm{~b}), 17: 33 \mathrm{~B}-1,17: 33 \mathrm{~B}-2$ (g), 17:33B-51 (West Supp. 1992).

46. In 1990 , Allstate had $15.9 \%$ of the market. Romano, supra note 4 .

47. Id. Companies that are currently in the process of withdrawing and have had their withdrawal plans approved include Colonial Penn Group (.5\% market share), CIGNA (1.4\% market share), American Policyholders ( $<1 \%$ market share), Crum \& Forster (.5\% market share), and John Hancock Group (.4\% market share). Other companies waiting to have their plans approved include Commercial Union Insurance Company (.1\% market share), Hartford Insurance Group (1.5\% market share), Home Insurance Company (.4\% market share), and Sentry Insurance Group (.2\% market share). Several major companies, including Geico, Unigard, Nationwide, and Safeco, left New Jersey several years ago because of poor profits, but they had small market shares. See New Jersey Insurance News Service (Mar. 1983) (unpublished news release, on file with author); Telephone Interview with John Tiene, Account Manager, New Jersey Insurance News Service (Sept. 2, 1992); Berg, supra note 42; Best DataBase Serv., New Jersey: All Private Pass. Auto, P/C Experience By State (By Line), at 14 (1991) (on file with author). Although the companies exiting the market now seem to have small market shares, most auto insurance companies in New Jersey insure less than $5 \%$ of the market. In December 1992, Allstate announced that it would remain in New Jersey for two more years in return for a rate increase of $6.5 \%$. In addition, Allstate has agreed to drop several lawsuits against New Jersey and will pay the state $\$ 75$ million to help cover the JUA's deficit. Wayne King, Auto Insurer Reaches Pact in New Jersey, N.Y. TiMES, Dec. 15, 1992, at B1. 
In April 1991, under FAIR, the Insurance Commissioner adopted new rules restricting the withdrawal of insurance companies from New Jersey ${ }^{48}$ These rules give the Insurance Commissioner significant discretion in fashioning withdrawal schedules for insurers. In order to withdraw, an insurer must submit a detailed plan for withdrawal containing an estimate of future claims against the company, the probable impact of its withdrawal on the market, the cause for the withdrawal, and certain actuarial information. ${ }^{49}$ This information allows the Commissioner to determine which provisions of the withdrawal statute should be applied to the withdrawing insurer, a determination that is left to the Commissioner's discretion. The Commissioner can require an insurer to give up all insurance licenses in New Jersey in order to withdraw from one market. ${ }^{50}$ For example, to withdraw from the auto insurance market, a company may also have to cease writing other more profitable types of insurance, such as fire insurance. Once a company has withdrawn, it cannot reenter the New Jersey market for up to five years without the Commissioner's permission. ${ }^{51}$ If the withdrawal involves private passenger auto insurance, the Commissioner can require that the insurer remain in the state for up to five years or until the withdrawing carrier has been able to place all its business with another insurer, whichever comes first. At the end of five years, if alternative coverage cannot be found, the insurer may start issuing nonrenewal notices. ${ }^{52}$ While withdrawing, the insurer must accept the quota of drivers from the MTF that the Commissioner assigns to it. ${ }^{53}$

The New Jersey courts have held all provisions of the Act constitutional, provided that the Commissioner enforces them so as to provide insurers a fair rate of return. The insurers have challenged the FAIR provisions forcing them to pay the debt of the JUA without passing this debt onto the insureds, ${ }^{54}$ the measures requiring them to insure the drivers in the $\pi \mathrm{UA}^{55}$ and the laws forcing insurance companies that do not write auto insurance to help pay the JUA's debt. ${ }^{56}$ In addition, Twin City Fire Insurance Company has claimed that withdrawal regulations requiring an insurer to give up all lines of insurance in order to withdraw from the auto insurance market are unconstitutional violations of the Takings Clause, the Due Process Clause, and the Equal Protection Clause. ${ }^{57}$ Twin City also objected to the retroactive

48. N.J. ADMIN. CODE tit. 11, § 2-29 (1991).

49. N.J. ADMIN. CODE tit. 11, §\$ 2-29.2 to 2-29.4 (1991).

50. N.J. ADMIN. CODE tit. 11, \& 2-29.3(c) (1991).

51. N.J. ADMIN. CODE tit. 11, § 2-29.3(f) (1991).

52. N.J. ADMIN. CODE tit. 11, § 2-29.5(a)(1) (1991).

53. N.J. ADMIN. CODE tit. 11, § 2-29.5(a)(2) (1991).

54. State Farm Mut. Auto. Ins. Co. v. State, 590 A.2d 191 (N.J. 1991).

55. In re Aetna Casualty \& Sur. Co., 591 A.2d 631 (N.J. Super. Ct. App. Div. 1991), cert. denied, 599 A.2d 162 (N.J. 1991), cert. denied sub nom. Allstate Ins. Co. v. Fortunato, 112 S. Ct. 1244 (1992).

56. In re American Reliance Ins. Co., 598 A.2d 1219 (N.J. Super. Ct. App. Div. 1991), cert. denied, 606 A.2d 369 (N.J. 1992).

57. In re "Plan for Orderly Withdrawal from New Jersey" of Twin City Ins. Co., 609 A.2d 1248, 1257 
application of the withdrawal scheme since the company had submitted its withdrawal application after the announcement of the FAIR Act but before the enactment of the regulations. Nevertheless, the New Jersey courts found the regulations constitutional. ${ }^{58}$

\section{B. Massachusetts}

Massachusetts also has enacted strict withdrawal regulations for auto insurance companies. Massachusetts law forces insurers to charge insureds premiums based on factors which often do not reflect the expected losses of that particular insured. ${ }^{59}$ The state serves its involuntary market with a reinsurance pool, but because of inadequate rates, the pool has had a deficit of over $\$ 500$ million per year, totaling over $\$ 3$ billion since the inception of the system. ${ }^{60}$ In 1988, 1989, and 1990, respectively, Massachusetts auto insurers had losses as a percentage of direct premiums earned of $-0.5 \%,-1.0 \%$, and $-2.5 \%$ and returns on net worth of $-0.8 \%,-1.3 \%$, and $-3.1 \%{ }^{61}$ Under Massachusetts regulations, in order to withdraw from the auto insurance market, a company licensed to write auto insurance in the state must submit a detailed withdrawal plan for the Commissioner's approval. ${ }^{62}$ However, the Insurance Commissioner. has the statutory right to suspend a withdrawing company's license to write any insurance in Massachusetts if, at a hearing, the Commissioner determines that the withdrawing company acted other than to protect its solvency. ${ }^{63}$ Another restriction is Commonwealth Automobile Reinsurers (CAR) Rule 11 B.3, which states that if a withdrawing automobile insurer wishes to keep its other licenses in the State of Massachusetts, it must pay its share of the involuntary market assessments for the three years following its withdrawal from the auto insurance market. ${ }^{64}$ Before the enactment of this rule, several insurance companies had withdrawn from Massachusetts after negotiating terms with the Department of Insurance. ${ }^{65}$

(N.J. 1992), cert. denied, 113 S. Ct. 1066 (1993); see supra notes 9, 10 for text of Takings Clause and Due Process Clause, respectively. The Equal Protection Clause states, "nor shall any State ... deny to any person within its jurisdiction the equal protection of the laws." U.S. CONST. amend. XIV, $\S 1$.

58. See infra Part IV for further discussion of the constitutional issues involved.

59. MASS. GEN. L. ch. 175, § 113H (1991) (Commissioner may establish rate categories for insurers); see also Douglas Bailey, Study Blames Regulators for High Auto Rates, BOSTON GLOBE, Aug. 30, 1989, at 69.

60. Douglas Bailey, Car Insurance: Free Market?, BOSTON GLOBE, Aug. 1, 1989, Econ. 21; MOONEY, supra note 4, at 59.

61. NAIC REPORT ON PROFTABILITY, supra note 37 (Profitability Results-Six Year Summary: Massachusetts). On all lines of insurance during these years, Massachusetts insurers earned profits of $5.6 \%$, $5.4 \%$, and $6.1 \%$ and a retum on net worth of $10.5 \%, 9.9 \%$, and $10.2 \%$. $l d$.

62. MASS. REGS. CODE tit. 211, $§ 54.01-54.06$ (1991).

63. MASS. GEN. L. ch. 175, § $22 \mathrm{H}$ (1991).

64. Rule of Operation 11, supra note 6.

65. These companies include: Peerless (which is involved in continuing litigation), Shelby, Fireman's Fund (which paid $\$ 45$ million), General Accident (which has not yet reached a settlement), Reliance, and Allstate (which is still engaged in litigation). Telephone Interview with Daniel Judson, Deputy General 
Allstate Insurance Company announced its withdrawal in 1988, stating that it had lost \$115 million over five years in the Massachusetts auto insurance market. ${ }^{66}$ Under various CAR Rules, Royal, St. Paul, Cigna, Chubb, Central Mutual, Aetna, and ITT Hartford have all withdrawn from the auto insurance market. Crum \& Forster and USF\&G are currently negotiating with the Department of Insurance for approval of their withdrawals. ${ }^{67}$

The Massachusetts courts have upheld the constitutionality of the state's withdrawal provisions. In 1977, the Supreme Judicial Court of Massachusetts ruled that the Commissioner's discretion to force a company to surrender all of its other insurance licenses in order to withdraw from the auto insurance market violated neither the company's equal protection nor its due process rights and did not involve an unconstitutional delegation of legislative power. ${ }^{68}$ In 1991, Reliance Insurance Company and several other insurers informed the Insurance Commissioner that they were withdrawing from the auto insurance market. ${ }^{69}$ Reliance claimed that since the companies were withdrawing, they were no longer members of the reinsurance pool and did not owe further payments. ${ }^{70}$ An appellate court rejected the company's reasoning. ${ }^{11}$

In 1990, Aetna Casualty and Surety Company filed suit in federal court claiming that $\S 22 \mathrm{H}$ and Rule 11 B. 3 were unconstitutional. ${ }^{72}$ Aetna claimed that, under the Massachusetts scheme, it would be compelled to pay $\$ 150$ million over eight years to cover the reinsurance pool's debt. ${ }^{73}$ In 1991, Massachusetts changed CAR Rule 11 B.3 to require that insurers only pay three years of involuntary market assessments to retain their other licenses, as opposed to the eight years previously required. As a result of this change, in January 1992 Aetna agreed to pay $\$ 87.5$ million to withdraw from the Massachusetts auto insurance market. ${ }^{74}$

\section{California}

In 1988, California passed "Proposition 103," a ballot initiative setting out new rules for the insurance industry, including a $20 \%$ "rollback" or reduction

\footnotetext{
Counsel of Department of Insurance of Massachusetts (May 11, 1991). at 20.

66. Douglas M. Bailey, Allstate Move No Joke to Rest of Industry, Boston GLOBE, Nov. 21, 1988,

67. Telephone Interview with Daniel Judson, Deputy General Counsel of Department of Insurance of Massachusetts (May 11, 1991).

68. Maryland Casualty Co. v. Commissioner of Ins., 363 N.E.2d 1087, 1098-99 (Mass. 1977).

69. Reliance Ins. Co. v. Commissioner of Ins., 581 N.E.2d 1027, 1028 (Mass. App. Ct. 1991).

70. Id.

71. Id. at 1033. See infra Part IV for further discussion of the constitutional issues.

72. Aetna Casualty \& Sur. Co. v. Gailey, 753 F. Supp. 46 (D. Mass. 1990). The State filed a motion to dismiss on the grounds that the rule had not yet been applied to Aetna. The court refused to grant the motion.

73. Id. at 48 .

74. Charles Stein, Aetna Quitting As Auto Insurer, Boston GloBE, Feb. 1, 1992, at 16.
} 
of auto insurance rates. The initiative also provided that rates could only be raised during the ensuing year if the insurer was "substantially threatened with insolvency." N5 Nonrenewal of a policy was allowed only for "one or more of the following reasons: (1) non-payment of premium; (2) fraud or material misrepresentation affecting the policy or insured; (3) a substantial increase in the hazard insured against."76 The Insurance Commissioner's rules subjected the insurance companies to essentially the same kind and intensity of regulation as is applied to public utilities. Prior to Proposition 103, a competitive market determined rates in California. ${ }^{77}$

California regulators have determined that auto insurers are entitled to approximately a $10 \%$ return on investment, while public utilities receive $14 \%{ }^{78}$ The Insurance Commissioner justifies this determination by claiming that $10 \%$ is the historic profit average for the auto insurance industry. ${ }^{79}$ However, if this were in fact the average, it would not be necessary in a competitive market to regulate the rates charged. In addition, it is inconsistent to allow stockholders whose competitive business is not protected from failure and loss of their investment a lower rate of return on their investment than stockholders of a public utility receive. In 1988, California insurers suffered losses of $-1.4 \%$, while in 1989 and 1990, they earned profits of $3.6 \%$ and $2.5 \%$, respectively, as a percentage of direct premiums earned. They had returns on net worth in the same years of $-2.2 \%, 5.3 \%$ and $3.6 \%$, significantly below the administratively designated $10 \%{ }^{80}$

With the exception of the nonrenewal policy in Proposition 103, no other provisions of the law prevent a company from withdrawing from the auto insurance market in California. An insurer may withdraw from the market by discharging its liabilities in the state, ${ }^{81}$ publishing its notice of withdrawal, ${ }^{82}$ submitting to an inspection by the Insurance Commissioner, ${ }^{83}$ and paying a small processing fee. ${ }^{84}$ The day before the vote on Proposition 103, Travelers Indemnity Company and several other affiliated insurers submitted applications for withdrawal in the statutory manner. To prevent these firms from exiting the market, the Insurance Commissioner ruled that the companies could not send out nonrenewal notices to their policyholders until they had been approved

75. CAL. INS. CODE $§ 1861.01(b)$ (West $1984 \&$ Supp. 1992).

76. CAL. INS. CODE $\$ 1861.03$ (c) (West 1984 \& Supp. 1992).

77. Sylvia Nasar, No Quick Fix for the Auto-Insurance Mess, U.S. NEWS \& WORLD REP., July 2, 1990 , at 46.

78. Louise Kertesz, Insurers Protest Prop. 103 Rules, Bus. INS., Aug. 26, 1991, at 3.

79. In re Determination of Rate of Return, Leverage Factor, and Projected Yield for 1989 Rate Calculations, File No. RCD-2 at 1-18 (Ins. Comm'n Ruling, Aug. 14, 1991).

80. NAIC REPORT ON PROFITABILITY, supra note 37 (Profitability Results-Six Year Summary: Califomia). California insurers earned profits on all lines of insurance of $8.7 \%, 8.3 \%$, and $7.5 \%$ and return on net worth of $13.7 \%, 12.4 \%$, and $11.0 \%$ in each of the respective years. Id.

81. CaL. INS. CODE $\S 1071.5$ (West 1972).

82. CAL. INS. CODE $\S \S 1071,1073$ (West 1972).

83. CAL. INS. CODE $\S 1072$ (West 1972).

84. CAL. InS. Code $\S 1076$ (West 1972 \& Supp. 1992). 
formally for withdrawal. ${ }^{85}$ The insurance companies filed suit, and the Supreme Court of California rejected the Commissioner's position:

We find nothing in the language of the withdrawal statutes suggesting that in the normal case the withdrawal process is to be other than simple and expeditious.

That language [of Proposition 103] plainly implied that the mandatory renewal provision does not apply to insurers who employ the statutory procedure for withdrawing from the California insurance market. $^{86}$

In so holding, the court rejected the Commissioner's attempt to make withdrawal a complicated process.

A number of insurers have challenged the constitutionality of Proposition 103. Although the Supreme Court of California upheld most of the provisions, it invalidated some parts of the initiative ${ }^{87}$ The nonrenewal restrictions were found to be constitutional. However, the court held that the provision preventing the Commissioner from approving rate increases for one year unless the insurer was threatened with insolvency was unconstitutional but severable from the rest of the initiative. In upholding the $20 \%$ rate rollback, the court imposed two conditions. First, the Commissioner could not order the rate rollback without allowing a hearing on the adequacy of these rates. Second, "[o]ver the long term, the state must permit insurers a fair return."

\section{ECONOMIC IMPACT OF WITHDRAWAL REGULATIONS}

Currently, legislators and regulators in some states seek to regulate the auto insurance market to ensure available and affordable coverage. ${ }^{89}$ Although regulators and legislators can force insurance companies to bear losses in the short run, in the long run the insurers will leave the market, thus undermining the dual objectives of available and affordable insurance. An examination of the economic incentives shows that this is the case.

\section{A. Short Term Effects}

Insurance companies in states with withdrawal restrictions must pay assessments that cover involuntary market plan deficits and charge rates below costs. Withdrawal restrictions prevent insurers from avoiding these costs by

85. Philip Hager, Court Asked to Limit Insurer's Right to Fold, L.A. TIMES, Nov. 8, 1989, at A24.

86. Travelers Indem. Co. v. Gillespie, 785 P.2d 500, 506-07 (Cal. 1990).

87. Calfarm Ins. Co. v. Deukmejian, 771 P.2d 1247 (Cal. 1989).

88. Id. at 1255.

89. See supra note 15 . 
leaving the auto insurance market. Such measures are only effective in shifting the high costs of auto insurance onto insurance companies in the short run until the insurers are able to satisfy the requirements to leave the market.

Until the insurer can exit the market, the company must operate under the insurance commissioner's conditions. In a state like New Jersey, this means that auto insurers will continue to suffer significant losses. New Jersey sets the premiums insurers can charge below the insurer's expected cost. At the price set by the Insurance Commissioner, the demand for insurance policies is significantly higher than the number of policies that can be sold profitably at that price, producing an excess demand for auto insurance policies.

In addition to keeping prices low, regulators want to make insurance available for most drivers. In order to make insurance available, regulators force insurers to sell more policies than they would otherwise sell at the ceiling price. Regulators in New Jersey have done this, ordering each auto insurer to absorb a portion of the drivers in the MTF. Thus, insurers suffer a loss on each policy they are required to sell for which the price charged falls short of the costs incurred. These losses continue until the insurer exits the market.

How long an insurer must stay in a state varies with the type of regulation. The restrictions in Massachusetts allow an insurer to withdraw from the auto insurance market at any time, but in order to withdraw, the company must pay a large fine or give up its other lines of insurance within the state. ${ }^{90}$ In contrast, in New Jersey the Commissioner can force an insurer waiting to withdraw to spend five years seeking alternative coverage for its policyholders. Moreover, during that time the insurer must continue to accept drivers transferred out of the involuntary market pool. ${ }^{91}$ Allstate, the largest insurer in New Jersey, has sustained huge losses in the New Jersey auto insurance market- $\$ 72$ million last year and $\$ 450$ million in the last twenty years. ${ }^{92}$ Allstate will continue to bear such losses until the state allows it to withdraw from the market. It is unlikely, if not impossible, that a company servicing a large segment of the market will find alternative coverage for its insureds in a market so feeble that it requires withdrawal restrictions.

When deciding whether to exit, insurance companies will weigh the losses they now incur in the auto insurance market against the profits they will lose as a result of a state's withdrawal requirements. For example, in New Jersey, an insurer must decide if its losses in the auto insurance market are high enough to justify relinquishing all other insurance licenses in that state. In Massachusetts, a company will compare the fine it must pay to the profits it earns in other lines of insurance before surrendering its license. Insurers in

90. See supra notes $62-64$ and accompanying text.

91. See supra notes 52-53.

92. See Berg, supra note 42. 
these states do not have to consider the probability of bankruptcy and its accompanying costs because the statutes and regulations allow the respective insurance commissioners to relax the rules for companies in financial trouble.

\section{B. Long Term Effects}

Withdrawal regulations, assessments, and rate rollbacks increase the costs and risks involved in doing business and make a company's profit projections uncertain. Although insurance companies initially will have to bear the losses the state imposes on them, eventually auto insurance will become harder and more expensive to obtain.

As withdrawal regulations, assessments, and rate reductions decrease the profit potential of the auto insurance business, fewer insurers will want to sell auto insurance. Insurers contemplating entering the market will consider the possibility that they will face large assessments from state involuntary plan deficits and artificially low rates. In addition, regulations that condition market exit on the surrender of all insurance licenses or the payment of a large fine increase the costs of writing auto insurance and discourage prospective business entrants. A new company will have to take these exit costs into account when deciding whether to enter the market. An insurance company in a state which does not yet have withdrawal regulations has an incentive to get out of that line in order to avoid the risk that it will become subject to regulations that impose increased costs. An insurance company already subject to these regulations eventually will withdraw from the state if forced to operate continually at a loss. If future entrants into the business are discouraged and current insurers leave the market, competition will decrease. Insurance will become harder to obtain.

The uncertainty of assessments, low rates, and withdrawal regulations not only will make insurance harder to obtain but also will make it more expensive. Suppose that in the future state regulators and legislators, deciding that current practices are counter-productive, repeal withdrawal restrictions and allow higher rates. Insurers still would be discouraged from entering the market because of uncertainty about future regulatory decisions and the risk that new restrictions will be imposed. For example, when New Jersey established the JUA, auto insurers did not expect to be individually liable for JUA claims or debts. ${ }^{93}$ The New Jersey courts subsequently held that insurance companies-even those companies that do not sell auto insurance-can be forced to pay these debts. ${ }^{94}$ The state has characterized the assessed payments as loans, but since they are not official state debt, there is

93. See State Farm Mut. Auto. Ins. Co. v. State, 590 A.2d 191, 207-08 (N.J. 1991); see also N.J. STAT. ANN. §§ 17:30E-1 to 17:30E-24 (West 1985 \& Supp. 1992).

94. In re American Reliance Ins. Co., 598 A.2d 1219 (N.J. Super. Ct. App. Div. 1991), cert. denied, 606 A.2d 369 (N.J. 1992). 
no guarantee that they will be repaid..$^{95}$ Forcing insurers to pay this debt is likely to cause more uncertainty than any other action the state may take in the New Jersey insurance market. A major part of the JUA plan was that any excess losses were to be made up by monies collected from fines and were not the insurers' responsibility. Putting this burden on the insurers significantly increased uncertainty in all insurance markets. While auto insurers did not expect to be held responsible for the JUA deficit, insurers who did not sell auto insurance had even less reason to guess that they would be responsible for a deficit from auto insurance sales. California law requires insurers to refund $20 \%$ of the rates they charged to customers in 1988 unless this refund would leave the company without a reasonable return. ${ }^{96}$ However, only three major companies have agreed to pay the refunds, while approximately eighty insurers still are involved in litigation protesting the rebates. ${ }^{97}$

Insurance companies will respond to uncertainty by demanding a risk premium to continue serving the market and to cover the risk that regulation or legislation will raise their costs significantly. As a result, the cost of supplying auto insurance will increase. This will cause a rise in the price of insurance policies which will in turn cause fewer policies to be sold since fewer drivers will be able to afford them. This chain reaction undermines the professed goals of regulators. If premiums continue to be held at a level that is artificially low relative to costs, less insurance will be available because current insurers will exit the market and few new businesses will take their place.

In defense of withdrawal restrictions, it has been argued that since auto insurance companies benefit from the enforced consumption of their product (due to state requirements that all drivers buy insurance) as well as from an exemption from federal antitrust laws, ${ }^{98}$ they should bear the burden of supporting the drivers in the involuntary market. Although this argument shows why it may be necessary to regulate the auto insurance market, it does not support the imposition of withdrawal restrictions. If insurers would rather leave the market than sell insurance under the conditions set out by the insurance commissioners, presumably they find that the benefits of a large market of drivers and exemption from the antitrust laws do not make up for the burdens involved. Therefore, if the insurers desire to exit the market, regulators cannot justify the implementation of withdrawal restrictions by pointing to the benefits insurance companies are receiving.

95. In re Loans of N.J. Property Liab. Ins. Guar. Ass'n, 590 A.2d 210 (N.J. 1991)

96. CAL. INS. CODE $\S 1861.01$ (b) (West 1984 \& Supp. 1992); Calfarm Ins. Co. v. Deukmejian, 771 P.2d 1247 (Cal. 1989).

97. See James F. Peltz, Insurance Chief Not Wavering; Proposition 103: The Feisty Chairman of 20th Century Industries Drives Home His View Opposing Rebates for Motorists, L.A. TIMES, Sept. 22, 1992, at B3; Kathleen Pender, Progressive Insurance Co. to Pay Prop. 103 Rebates, S.F. ChroN., June 13, 1992, at B1.

98. McCarran-Ferguson Act, 15 U.S.C. \$§ 1011-1015 (1988). 


\section{Cross-Subsidization}

Forcing multi-line insurance companies to stay in the market and charge rates below expected claims causes the insurers to subsidize auto insurance with profits from other lines. Both California and New Jersey insurance regulations contemplate that auto insurers will engage in such crosssubsidization. A New Jersey statute forbids insurers from passing on to consumers any of the charges the insurers are assessed to pay for the JUA deficit. ${ }^{99}$ If insurers are dissatisfied with the rate of return from current premiums, insurers may apply to the Insurance Commissioner for a higher rate and pass some of the assessments on to the insureds. In determining whether an insurer is entitled to a rate increase to reflect these assessments, the Commissioner is allowed to consider, "[ $t]$ he insurer's experience on all lines of its business in New Jersey."100 Even though the Commissioner is to assure a fair rate of return, he can allow the insurance rates charged in other lines of insurance to subsidize auto insurance.

California has allowed cross-subsidization in a less obvious way. The State permits each insurer a profit of $10 \%$ of its reserves, but limits the amount of actual reserves each insurer may use for this calculation. ${ }^{101}$ Reserves are the funds an insurer has available to service claims. The trend has been toward maintaining higher reserves because increasing auto insurance losses mean more reserves are necessary to cover each policy. ${ }^{102}$ California thus risks pushing insurers into insolvency. By failing to include all reserves for profit calculation, it encourages maintenance of lower actual reserves. ${ }^{103}$ Before 1988 , auto insurance rates were determined by competition among the insurers. The state now requires that insurers include in their profit calculations fewer reserves than the insurers were maintaining voluntarily when their the state did not control their profits. If a company chooses to keep higher reserves, auto insurance will be subsidized by the other lines of insurance that the company supplies, and, thus, by the companies' stockholders in the form of reduced profits on the company's other lines of insurance. ${ }^{104}$

Regulators often force cross-subsidization in the public utilities context. ${ }^{105}$ For example, regulators may require an electric utility to charge

99. N.J. STAT. ANN. \& 17:30A-16b (West 1985 \& Supp. 1992).

100. N.J. ADMIN. CODE tit. 11, § 3-16.11(d)(1) (1991).

101. CAL. CODE REGS. tit. 10, § 2645.6 (1991).

102. In re Determination of Rate of Return, Leverage Factor, and Projected Yield for 1989 Rate Calculations, File No. RCD-2 at 19-29 (Ins. Comm'n Ruling, Aug. 14, 1991).

103. See Jerry Geisel, Headaches at Home and Abroad: Political Ploys Endanger U.S. Insurance Solvency, Warns Joint Meeting Panel, Bus. INS., Jan. 20, 1992, at 3 (discussing risk of insolvency when insurers are forced to charge excessively low rates and predicting that more insurance companies will withdraw from auto insurance market).

104. See Kertesz, supra note 78 (quoting insurers saying that California auto rates are so low that other lines of insurance and insureds in other states will be forced to subsidize California auto insurance).

105. See Richard A. Posner, Taxation by Regulation, 2 BELL J. ECON. \& MGMT. SCI. 22, 40 (1971). 
the same rate to all customers even though it is more expensive to service customers who are farther away from the plant. Although cross-subsidization within public utilities may be undesirable, ${ }^{106}$ the effects of such distortions are less evident than in the competitive insurance market. Public utilities are given monopolies in their markets and thus will not be placed at a competitive disadvantage in the market they use to subsidize the market that is generating losses.

When multi-line insurance companies are forced to subsidize auto insurance with profits from other lines, they must either charge higher prices in those other markets or accept a lower overall rate of return on their capital. If they do the latter, they ultimately will be unable to attract investors because the return on the insurers' capital will be lower than other investments of comparable risk. Yet, if they do the former, then companies that do not sell auto insurance will be able to enter those markets and charge lower premiums, since they do not have to subsidize the sale of auto insurance. This means that if auto insurers are able to charge higher rates in other insurance markets, they will only be able to do so for a short time. Thus, auto insurers will be forced to use part of the profits they would normally earn from other lines of insurance to subsidize the sale of auto insurance.

When a public utility is forced to cross-subsidize, it can make up for lost profits by increasing prices in other markets because public utilities are typically monopolies. For example, if a public utility is forced to charge all consumers the same price even though servicing some consumers involves greater cost, the utility can raise the price charged to all consumers since there are no competitive forces in the market. Any consumer who wants the public utility's service is required to pay the price charged. When withdrawal restrictions prevent an auto insurance company from exiting the market by withdrawal restrictions, the firm must resort to cross-subsidization and lower profits. Public utilities are generally protected from insolvency by regulators, whereas insurance companies are not. Automobile insurers operate under the same constraints as public utilities but without commensurate protections.

\section{THE CONSTITUTIONALITY OF WITHDRAWAL RESTRICTIONS}

Not only are withdrawal regulations economically inefficient and counterproductive, but courts should find them unconstitutional. States have a legitimate interest in preserving insurance coverage for all drivers and preventing disruption while insurers exit the market. However, the current

This article discusses the effects of cross-subsidization for utility type monopolies, but some of the observations are relevant to the insurance context. Cross-subsidization provides a subsidy to auto insurance from insureds in other states and from purchasers of other lines of insurance which is hidden from public view. Id. at 43.

106. See id. at $43-44$. 
regulations discussed above go too far. Forcing insurers to remain in the auto insurance market violates substantive due process and represents an unconstitutional taking.

The jurisprudence interpreting the Takings Clause and Substantive Due Process rights is confusing and often contradictory ${ }^{107}$ Especially in the area of rate regulation, there is disagreement among both courts and scholars over whether the restraint on regulation comes from the takings clause or from substantive due process doctrine. Since the Supreme Court has provided more precedent in the takings area, most courts discuss takings and due process analysis in tandem without distinguishing the two. ${ }^{108}$ Despite the Court's concentration on takings analysis, it is useful to consider the arguments supporting a due process violation.

The withdrawal provisions in New Jersey and Massachusetts allow the Insurance Commissioner to condition an auto insurer's withdrawal on the surrender of its other insurance licenses within that state. Although insurers have challenged most aspects of the withdrawal schemes imposed by these states, this forfeiture condition is the most significant because of the financial losses such provisions impose. Both the Massachusetts and New Jersey courts have rejected challenges to such forfeiture provisions. In Maryland Casualty Co. v. Commissioner of Ins. ${ }^{109}$ the Supreme Judicial Court of Massachusetts upheld the statute requiring the insurer to surrender all insurance licenses in order to exit the auto insurance market. The court devoted only one sentence to its rejection of the insurer's arguments that the law violated its due process rights and was an unconstitutional delegation of legislative power. "We have reviewed these arguments," the court stated, "and find that they are without merit." 110

The New Jersey Supreme Court was more troubled by similar arguments in In re "Plan for Orderly Withdrawal from New Jersey" of Twin City Fire Ins. Co. ${ }^{111}$ Twin City Fire Insurance Company, a subsidiary of ITT Hartford, challenged regulations forcing Twin City's affiliated insurance companies to surrender their licenses to sell insurance in other lines if Twin City withdrew from the auto insurance market. The insurer and amicus curiae made several

107. See Lawrence Blume \& Daniel L. Rubinfeld, Compensation for Takings: An Economic Analysis, 72 CAL. L. REV. 569 (1984); Carol M. Rose, Mahon Reconstructed: Why the Takings Issue is Still a Muddle, 57 S. CAL. L. REv. 561, 566-69 (1984).

108. See Blume \& Rubinfeld, supra note 107 (criticizing court decisions in regulatory takings cases); John N. Drobak, From Turnpike to Nuclear Power: The Constitutional Limits on Utility Rate Regulation, 65 B.U. L. REV. 65 (1985) (discussing the Supreme Court's development of constitutional limits on economic regulation); Sean P. Madden, Note, Takings Clause Analysis of Utility Ratemaking Decisions: Measuring Hope's Investor Interest Factor, 58 FORDHAM L. REV. 427 (1989) (criticizing court interpretations of return that public utilities must receive).

109. 363 N.E.2d 1087 (Mass. 1977).

110. Id. at 1099.

111. 609 A.2d 1248 (N.J. 1992), cert. denied, 113 S. Ct. 1066 (1993). 
challenges to the constitutionality of the provision, ${ }^{112}$ the strongest of which were the claims that the forfeiture condition violated the insurer's substantive due process rights and worked an unconstitutional taking of property without compensation. The Massachusetts and New Jersey courts that have considered these claims have decided them incorrectly.

\section{A. Substantive Due Process}

In Twin City, the New Jersey Supreme Court rejected the insurers' claims that the withdrawal conditions violated the company's substantive due process rights. The court drew on the substantive due process doctrine of the U.S. Supreme Court: "[A] state statute does not violate substantive due process if the statute reasonably relates to a legitimate legislative purpose and is not arbitrary or discriminatory." 13 The Twin City court refused to label the withdrawal regulations arbitrary or discriminatory because it would be "inequitable" for "an insurer who enjoyed profitable operations during the pre-Reform Act period [to] abandon entirely the remedial burdens imposed by the Act on all private-passenger insurers." 114 The court determined that New Jersey had a compelling interest in preventing insurers from leaving the state and that the forfeiture condition reasonably accomplished state goals. ${ }^{115}$ Although the court initially advanced the New Jersey Insurance Commissioner's justifications supporting the withdrawal provisions, it did not specify which line of reasoning supported its finding that the provisions were not arbitrary and discriminatory. The Commissioner offered two justifications for imposing the forfeiture condition on automobile insurers. First, the Commissioner condemned as unfair the insurers' attempts to leave the state's auto insurance market while profiting on other lines of insurance. ${ }^{116}$ Second, the Commissioner contended that because auto insurers enjoyed favorable operating conditions in the past, they should not be allowed to abandon the market when it becomes unprofitable. ${ }^{117}$

112. The insurers and amicus curiae made other claims which are not as strong as the two claims discussed in the text. These include: 1) the regulation forcing an auto insurer to try to place its insureds with another carrier for five years is an unconstitutional taking; 2) the regulation requiring insurers withdrawing from the market to continue to accept new insureds from the depopulation of the MTF until they have formally withdrawn is a violation of due process; 3 ) the forfeiture condition violates the unconstitutional conditions doctrine; 4) the application of the regulations violates Twin City's equal protection rights. Id. at $1253-54,1260-61,1265$.

113. In re "Plan for Orderly Withdrawal from New Jersey" of Twin City Fire Ins. Co., 609 A.2d 1248, 1258 (N.J. 1992), cert. denied, 113 S. Ct. 1066 (1993) (quoting Greenberg v. Kimmelman, 494 A.2d 294 (N.J. 1985)). U.S. Supreme Court cases also use the arbitrary and irrational standard. See Duke Power Co. v. Carolina Envtl. Study Group, 438 U.S. 59, 82-84 (1978); Usery v. Turner Elkhorn Mining Co., 428 U.S. 1, 15 (1976); Ferguson v. Skrupa, 372 U.S. 726 (1963).

114. Twin City, 609 A.2d at 1259.

115. Id. at 1260 .

116. Id. at 1257 .

117. Id. at 1259. 
Neither of these arguments is tenable. The Commissioner's first line of reasoning fails because New Jersey regulations arbitrarily single out automobile insurers from among all insurers to subsidize the sale of auto insurance. The court found it unfair for auto insurers to profit on other lines while withdrawing from covering drivers. Under this reasoning, the regulations should require all insurers to sell to drivers in order to do any business in the state. Multi-line insurers who sell auto insurance operate at a disadvantage when compared with insurers only servicing other lines.

Second, the Commissioner argued that fairness requires auto insurers who have previously earned profits in the New Jersey auto insurance market to bear the burden of these new regulations. However, it is not "inequitable" for insurers to earn income when market conditions are favorable and to exit when business is no longer profitable. Private business exists to earn profits for its investors. If New Jersey wants private auto insurers to continue to operate in the state, the legislature should create a regulatory climate more favorable to insurers.

The Commissioner has submitted a third justification, though one not discussed in this case, to justify singling out auto insurers. The Commissioner has suggested that because auto insurer mismanagement produced the large JUA deficit, auto insurers should remain in the market until the state resolves its auto insurance problems. ${ }^{118}$ This rationale is untenable as well. The New Jersey Department of Insurance determined that the JUA deficit and high auto insurance premiums derived mainly from the number of cars, the level of legally required coverage, the maintenance of low rates for high-risk drivers that populated the JUA, and other regulation-related factors. ${ }^{119}$ New Jersey insurers did not create these problems. If the regulators consider insurers to be at fault, then New Jersey should bring legal action. Without a judicial determination of liability, the Insurance Commissioner has no right to collect damages from the auto insurers.

\section{B. Takings}

The forfeiture condition also works an unconstitutional taking of property without compensation. In Twin City, the New Jersey court discussed U.S. Supreme Court precedent, including the leading regulatory takings cases, ${ }^{120}$ and noted that in the "handful of cases involving regulatory 'takings' of commercial property interests other than land, the Court generally has been

118. 1989-1 NAIC PROC., supra note 12, at 5 .

119. See supra notes $39-41$ and accompanying text.

120. See, e.g., Lucas v. South Carolina Coastal Council, 112 S. Ct. 2886 (1992); First English Evangelical Lutheran Church v. County of Los Angeles, 482 U.S. 304 (1987); Hodel v. Irving, 481 U.S. 704 (1987); Keystone Bituminous Coal Ass'n v. DeBenedictis, 480 U.S. 470 (1987). 
reluctant to conclude that compensation is required."121 The Twin City court applied a three-factor balancing test to determine whether a compensable taking had occurred, considering: "the character of the governmental action, ${ }^{122}$ the economic impact of the regulation, and whether the regulation interfered with reasonable investment-backed expectations." 123 Concluding that the regulation satisfies the significant public interest of keeping auto insurers in New Jersey, the court found that the first factor supported the constitutionality of regulation. However, without evidence, the court could not determine the extent of the insurers' losses from enforced surrender of their licenses. Finally, it concluded that the third factor, the insurers' expectations, "lends itself to either side of the argument."."24

Contrary to the Twin City court's conclusion, the state's withdrawal regulations bear no rational relation to an attempt to make auto insurance available to New Jersey residents. The conditions imposed will not keep other insurers from abandoning the market. As insurers start exiting the market, drivers will have to find coverage from the remaining insurers. In addition, the number of remaining insurers will decrease as the state continues to depopulate the MTF. Initially, the remaining companies might possibly increase their earnings by absorbing profitable nonauto insurance business from departing companies. However, these increased profits will disappear in the face of losses from taking on a larger share of the unprofitable auto insurance business. In addition, insurers who do not service the auto insurance market may well pick up the nonauto insurance lines of withdrawing insurers.

The Commissioner's suggestion that the new business available will attract insurance companies to serve the auto insurance industry ${ }^{125}$ demonstrates the fallacy of the state's scheme. A new entrant to the New Jersey market will sell only the profitable types of insurance that the regulations force Twin City to abandon. Because regulations make the auto insurance market unprofitable, no new insurers will enter that market.

Even assuming arguendo that the policy achieves a significant public interest, the other two factors outweigh the interest test. The regulation has a significant, adverse economic impact. The court "[took] for granted . . . that the surrender by Twin City's affiliates of their respective licenses would not necessarily result in the elimination of all commercial value." 126 However, contrary to the court's assumption, other insurers will have no need to buy Twin City's affiliates' business because they can obtain it free once regulators

121. Twin City, 609 A.2d at 1263 (citations omitted).

122. The court interpreted this factor to mean that the state's action must further a substantial state interest. $I d$.

123. Id. at 1262 (citations omitted).

124. Id. at 1264 .

125. Id. at 1257.

126. Id. at 1264 . 
force Twin City to leave the market. An insurer will suffer a substantial economic impact from its affiliates' surrender of their licenses. Moreover, the insurers have a reasonable investment-backed expectation of a fair rate of return. They had no opportunity to surrender their auto insurance license before the regulations went into effect, and the insurers had no notice that the state would link the sale of auto insurance to other licenses.

\title{
C. Basis for Determining Profitability
}

In order to determine if there has been a taking, courts must determine the economic impact of the withdrawal regulations. To do this, they must decide the basis for determining profitability. In the Twin City case, New Jersey regulators argued for the constitutionality of withdrawal restrictions by pointing to Twin City's profits on its nationwide automobile insurance. ${ }^{127}$ The court summarized the Commissioner's claims, stating:

The Commissioner pointed out that Twin City's automobile-insurance business historically had been profitable on a national basis, that he assumed that Twin City's automobile business would continue to be profitable under the Reform Act, and that he did not accept Twin City's assertion that its automobile business would be unprofitable. ${ }^{128}$

Neither the court nor the Commissioner explained why the company's nationwide automobile insurance profits were the relevant measure. Since the court focused on the forfeiture condition, lines of insurance sold within New Jersey presented a more obvious basis for measuring profits. The courts have avoided this question of basis and failed to define a general rule for computing reasonable rates of return in takings cases. When courts determine whether an auto insurer is receiving a fair rate of return, they should measure the return from the auto insurance line in one state only. Measuring the rate of return by the insurer's operations as a whole creates inefficient cross-subsidies and puts auto insurers at a competitive disadvantage. ${ }^{129}$

The courts that have examined state assessment plans and withdrawal restrictions have affirmed that insurers must be guaranteed a fair rate of return, although they have not specified the components of that rate. In State Farm, the Supreme Court of New Jersey, quoting FPC v. Hope Natural Gas Co., ${ }^{130}$ stated that a fair rate of return "should be commensurate with returns on investments in other enterprises having corresponding risk." "131 However, the court also said that "while government regulation cannot wreak too great an

\author{
127. Id. at 1257 . \\ 128. Id. \\ 129. See supra Part III(C). \\ 130. 320 U.S. 591 (1944). \\ 131. State Farm Mut. Auto. Ins. Co. v. State, 590 A.2d 191, 199 (N.J. 1991) (citations omitted).
}


interference with 'distinct investment-backed expectations,' a participant in a highly regulated industry must anticipate that its profit levels can be capped or even reduced by changes in government regulation. There is no constitutional entitlement to maximum profits." 132 The issue of the proper unit for measuring return has not been considered in the context of the regulation of insurance. In In re Aetna, a New Jersey court said that an insurer does not have a "right to make money on every policy written, or on every day of business." 133 However, the New Jersey Supreme Court has also held that insurance companies are entitled to a level of profit that is "adequate to attract and retain invested capital." 134

The U.S. Supreme Court has not specified the basis for determining whether a taking has occurred within the meaning of the Fifth Amendment. In several of the leading takings cases, the Court has failed to define clearly a method for measuring the diminution of value. ${ }^{135}$ As Justice Scalia recently stated for the Court in Lucas v. South Carolina Coastal Council: $:^{136}$

[T] he rhetorical force of our "deprivation of all economically feasible use" rule is greater than its precision, since the rule does not make clear the "property interest" against which the loss of value is to be measured. When, for example, a regulation requires a developer to leave $90 \%$ of a rural tract in its natural state, it is unclear whether we would analyze the situation as one in which the owner has been deprived of all economically beneficial use of the burdened portion of the tract, or as one in which the owner has suffered a mere diminution in value of the tract as a whole. ${ }^{137}$

An examination of the major takings cases confirms Justice Scalia's statement. One of the most important regulatory takings cases, Pennsylvania Coal Co. v. Mahon, ${ }^{138}$ used the property being taken as the measure of the loss. The case involved a Pennsylvania statute which barred coal mining that resulted in the subsidence of any land supporting housing or certain public facilities not owned by the coal company, even when the coal company owned the right of support to the land. As the basis for computing the diminution in value, Justice Holmes' majority opinion used the value of the coal the company was forced to leave in the ground. "To make it commercially

132. Id. at 200.

133. In re Aetna Casualty and Sur. Co., 591 A.2d 631, 642 (N.J. Super. Ct. App. Div. 1991), cert. denied, 599 A.2d 162 (N.J. 1991), cert. denied sub nom. Allstate Ins. Co. v. Fortunato, 112 S. Ct. 1244 (1992).

134. State Farm, 590 A.2d at 199 (N.J. 1991). In addition, when considering Proposition 103, the Supreme Court of California mandated insurers' entitlement to a fair rate of return on their investment. Calfarm Ins. Co. v. Deukmejian, 771 P.2d 1247, 1255 (Cal. 1989).

135. See Rose, supra note 107 (summarizing inconsistencies in Court's diminution in value test).

136. 112 S. Ct. 2886 (1992).

137. Id. at 2894 n.7.

138. 260 U.S. 393 (1922). 
impracticable to mine certain coal," Holmes reasoned, "has very nearly the same effect for constitutional purposes as appropriating or destroying it." ${ }^{139}$ In dissent, Justice Brandeis argued that when evaluating the severity of a diminution of value in order to determine whether a taking has occurred, the court should consider the value of the coal relative to the value of the land as a whole rather than merely the value of the coal that must be left in the ground. ${ }^{140}$

This area of the law has remained confused for the balance of the century. In Keystone Bituminous Coal Ass'n v. DeBenedictis, ${ }^{141}$ the Court found that a coal company deprived of the right to mine a portion of its land did not show that there was sufficient diminution in value to constitute a taking. The Court refused to consider the coal required to be left in the ground as the relevant basis, as had been done in Pennsylvania Coal, and instead looked to the company's total mining operations as the basis for determining the diminution in value. Similarly, in Penn Central Transportation Co. v. New York, ${ }^{142}$ the Court approved the New York City Landmark Commission's prohibition on the construction of an office tower above Grand Central Terminal because the station was still economically viable in its traditional use. The Court used the station's profits as a whole, and not the lost profits from the company's inability to use the airspace, as the basis for determining the loss.

Although recent cases have found a broader basis than that used in Pennsylvania Coal, Justice Scalia's recent mention in Lucas of the inconsistency in the Court's decisions may signal future reconsideration. Justice Scalia may have further signalled a changing attitude when he described as "unsupportable" the view of the New York Court of Appeals quoted in Penn Central:

For an extreme-and, we think, unsupportable-view of the relevant calculus, see Penn Central Transportation Co. v. New York City ... . where the state court examined the diminution in a particular parcel's value produced by a municipal ordinance in light of total value of the taking claimant's other holdings in the vicinity. ${ }^{143}$

Courts have abdicated their responsibility to provide a workable standard. Takings analysis should not depend on the overall income of the property owner or business proprietor. The basis for determining whether a deprivation of property is a "taking" should be the value of the property itself, that piece of beach or line of business, because it will demonstrate the true impact of the

139. Id. at 414 .

140. Id. at 419.

141. 480 U.S. 470 (1987).

142. 438 U.S. 104 (1978).

143. Lucas v. South Carolina Coastal Council, 112 S. Ct. 2886, 2894 n.7 (1992) (citations omitted). 
regulators' decisions. The economic impact of regulating away the profitability of an entire line of business, auto insurance, imposes a dire penalty on insurers in that line and produces perverse economic incentives that distort the insurance market and render it inefficient.

\section{CONCLUSION}

Withdrawal restrictions have a detrimental effect on the auto insurance market. While legislators may seek to make insurance available and affordable, withdrawal restrictions only make the fulfillment of this goal less likely. In the long run, these regulations will make insurance harder to obtain and more expensive. The costs that these regulations impose will discourage new firms from entering the market and will encourage insurers presently in the business to exit as soon as possible.

The courts should find that the forfeiture condition in New Jersey's and Massachusetts' withdrawal regulations violates the insurer's due process rights and works an unconstitutional taking. By compelling insurers to supply auto insurance below cost, current rate regulations force insurers to supply a public service without compensation. When measuring whether insurers are receiving a fair rate of return, courts should designate the company's return on auto insurance in one state, not its aggregate return on all lines, as the relevant unit.

Legislatures need a comprehensive plan to deal with the crisis in auto insurance. Rising insurance costs and premiums force drivers into the involuntary market and increase the amount of subsidization. States will not achieve their goals of available and affordable insurance for all drivers by forcing insurance companies to supply auto insurance below cost. 


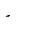

